\title{
Kinship and emergence of political leaders in Pakhtun society: A comparison of ANP and JUI-F in electoral politics in Charsadda, Pakistan
}

\author{
Mubasher Hassan* | Mohammad Taieb \\ Department of Anthropology, University of Peshawar, Peshawar, Pakistan. \\ *Corresponding Author Email: mubasher.anthro84@gmail.com
}

Received: April 11, 2021

Published: September 11, 2021

\begin{abstract}
The purpose of this paper is to describe kinship system and its relationship with the emergence of political leaders in district Charsadda, Khyber Pakhtunkhwa (KP). This study elaborates the role of kinship in the emergence of leaders at micro levels i.e., Village Council, Union Council, Tehsil Council and District Council. The study analyses the impact of kinship in the electoral politics of Awami National Party (ANP) and Jamiat Ulama-e-Islam Fazlur Rehman (JUI-F). The ANP leaders and followers are mostly the local inhabitants of Charsadda having large number of kin members. While on the other hand, the JUI-F leaders and followers are mostly immigrants of the other districts of KP having limited number of kin members in tehsil Charsadda. However, at micro level both the parties' leaders and their family members attempt to make fusion against the distant relatives in order to win the election. This paper describes that how the number of kin members directly affects the victory and defeat of ANP and JUI-F? This study argues that kinship and neighbourhood have significant impact in the emergence of leaders at micro level. Qualitative research method was used and the tools for data collection were participant observation, in-depth interviews and focus group discussions.
\end{abstract}

Keywords: kinship, political leaders, electoral politics, micro politics, internal immigrants, neighbourhood, secular political party, religious political party.

\section{How to Cite:}

Hassan, M. \& Taieb, M. (2021). Kinship and emergence of political leaders in Pakhtun society: A comparison of ANP and JUI-F in electoral politics in Charsadda, Pakistan. Journal of Humanities, Social and Management Sciences (JHSMS), 2(2), 26-41. https://doi.org/10.47264/idea.jhsms/2.2.3

\section{Publisher's Note:}

IDEA PUBLISHERS (IDEA Journals Group) stands neutral with regard to jurisdictional claims in the published maps and institutional affiliations.

\section{Copyright:}

(C) 2021 The Author(s), published by IDEA PUBLISHERS (IDEA Journals Group)

This is an Open Access article published under the Creative Commons Attribution-NonCommercial 4.0 International License (http://creativecommons.org/licenses/by-nc/4.0/) 


\section{Introduction}

In developing countries family and kinship are considered basic determinants for the emergence of political leaders as well as shaping the behaviours of voters (Rais, 1985; Wilder, 1999; Ahmed, 2013; Omale \& Amana, 2014). Among these, some scholars shed light on dynastic/ patrimonial politics while other are interested in family role in shaping the voting behaviour's. In Pakistan, like other developing societies, kinship plays a significant role in electoral politics for the emergence of political leaders (Lindholm, 1977; Khan, 1986; Mohmand, 2011; Martin, 2016; Shah, 2020). However, most of these studies discusses the role of family and kinship at macro national and provincial assembly levels. The scarce literature related to the role of kinship in politics did not explain the emergence of leader at micro level in KP. The study is mainly focused on the role of kinship in the emergence of political leaders at micro level electoral politics. Micro level refers to election of political leaders at the grassroot level i.e., Village Council (VC), Union Council (UC), Tehsil Council and District Council. This paper elaborates the role of kinship in electoral politics among the Pakhtuns ${ }^{1}$ of Charsadda and compares its role in the emergence of secular and religious political leaders.

Pakistan has multiparty system, different secular and religious parties compete during elections. However, for this study, Awami National Party (ANP), an ethno-nationalist political party and Jamiat Ulama-e-Islam Fazlur Rehman (JUI-F), a religious political party were selected. ANP claims for the socio-economic and political development of Pakhtuns ethnic group. While JUI-F claims for the implementation of Sharia laws based on Islamic jurisprudence. From the empirical data it reveals that the ANP leaders and followers are mostly local inhabitants of Charsadda. However, majority of JUI-F leaders and followers are immigrants ${ }^{2}$ from other districts of KP, particularly Bajure, Mohmand and Malakand districts. This paper shed light on different scholar's studies that shows the relationship between kinship and politics. In addition, with the help of literature it also provides a short background of grass root governments implemented in different times since the partition of the sub-continent. Moreover, a statistical analysis is also given in order to show the vote bank of ANP and JUIF. This study finds that among the Pakhtuns of Charsadda, kinship and neighbourhood are important variables for an electoral candidate for winning election at micro level. For more than three decades, in the area under study, ANP and JUI-F are trying to compete each other in electoral politics. However, at micro level the former party is more powerful in terms of voters compare to the later one. This study tried to elaborate on that what are the major causes of emergence of political leader at micro level? In addition, it tried to explore that why ANP won majority of seats at micro level compared to JUI-F? This paper argues that kinship compensates all the weaknesses of an electoral candidate during election.

\section{Literature review}

In most societies of the world, people live within much more complex social structures, connected with extended kin networks. The unilineal descent groups, common ancestor, presence of different segments or sub-sets, taking corporate forms are the characteristic features of kinship system (Fortes, 1953; Smith, 1956; Kurtz, 2001; Ahmed, 2013). These features play significant role in the emergence of political leaders. In short, kinship is defined as "the logical consistent system by which people classify their relatives into labelled categories or kind of relatives" (Peoples \& Bailey, 2011, p. 205). On the basis of different kinship categories, folk have socio-political expectations from one another. 
Lewis (1974, pp. 50-53) defines leader as "a person who initiates action and plays central roles in group decision-making”. Shore (2014, p. 178) suggests that leadership can be understood in at least two ways i.e., institutional office-holding and between members of a group. A leader is someone who convinces a group to follow a particular course of action. In this sense, more anthropological studies concerned with "the interaction between leader and followers". Moreover, Elgie (2001, p. 578) argues that leadership is "a reciprocal and essentially noncoercive relationship". Sahlins (1963, p. 290) opined that "leadership is a creation of followership." For this research, political leader means a person who acquires the position through electoral politics at micro levels elections. It is pertinent to illustrate the views of various scholars related to kinship, leader and leadership, and the kinship's role in the emergence of leader.

\subsection{The role of kinship in politics}

Fortes and Evan-Prichard (1940) while studying the political aspect of kinship in African societies identified that lineage, especially segmentary linage, as a territorial based political association is rooted in kinship relations. In addition, they suggested that segmentary lineage was lacking centralized government, it was a territorial unit that controlled political relations within and between related lineages and with external groups with whom they were not related. The primary political function of lineage is to uphold order and enforce conformity to lineage norms. Ahmed (2013, pp. 110-129) argues that Kanuri lineage in Nigeria and Yemeni tribes in Asir produced leaders like Boko Haram and Osama Bin Laden respectively. These leaders emerged purely on the basis of their kinship. Hammel (2005, p. 11954) suggests that in the African, near Eastern and central Asian segmentary societies politics may be understood with frequently cited Arab proverb "I against my brother, my brother and I against my cousin, my cousin and I against the stranger".

A recent study while comparing the 145 sub-Saharan African societies, Moscona et al. (2017, p. 50) suggested that segmentary lineage societies are more prone to conflicts while there is no evidence on record that it prevents conflicts. In addition, they also suggest that this hypothesis is also applicable to non-African societies. While generalizing the African segmentary societies across the continent, is over-estimation. Barth (1981, p. 58) identified that the basic principles of Pakhtuns kinship system i.e., descent and equivalence of siblings are clearly embodied in Radcliffe-Brown (1950) structure, but when "they are utilized in political contexts are only superficially reminiscent to African lineage organization". He further added that the charters of unilineal descent define territorial units and administrative councils but in a system of political alliance individuals are free by their own choice to align themselves in a political dual division. Hence, the aforementioned literature depicts that most of the studies conducted by researchers have recorded the conflicting aspect of segmentary lineage systems.

This paper is primarily concerned to demonstrate that how significant role kinship system plays in the emergence of leadership through electoral process. On electoral politics, abundant literature is available which grasps kinship and family role in the electoral process of Pakistani politics. Mushtaq et al. (2013) while discussing parties' leaders argue that a small number of families continue to dominate Pakistani political parties. Shah (2020, p. 130) opined that each political party is considered the property of a particular family. In this sense, ANP is the party of Khan Abdul Ghaffar Khan (Bach Khan) family and JUI-F is the party of Maulana Mufti Mahmud family. However, the focus of this study is not to discuss dynastic and patrimonial 
politics rather it tries to elaborate the extent of family and kinship on grass-root level to persuade voters. Khan (1986) explained that in the social structure of Pakistan khel and baradari still have a great influence. He further argues that it has a strong bearing while electing a leader from the group. Besides, family reputation, which helps people in distress, leaves a major reciprocal impact that compels them to go for voting in his favour. A study of Martin (2016, p. 97) on a Panjabi rural society in Pakistan argues that powerful agnatic kinship group is key actor in the local electoral process. He explained that how powerful landlords and their kin members adopt different strategies and tactics to compel the poor servants and peasants for casting vote in the landlords' favour. Hence, Martin's (2016) study only shows the coercive power of landlords during electoral process in negative aspects.

In contrast, the situation under study is otherwise. However, the finding of this study is similar to Mohmand (2011) and Shah (2020). While studying the Punjabi society Mohmand (2011) argues (as cited in Shah, 2019, p. 257) that modern technology has changed the social structure of every society. She stated that infrastructure and urbanization led political mobilization in rural Punjab. Modernization amplified the autonomy of voters but still the voters ${ }^{\text {ee }}$ relationship with local landlords as patron-client. She opines that social structure and caste system are the major determinants of voting behaviour for villages in Punjab. Similarly, Shah (2020, p. 257) argues that like the Chaudharys (landlords) of Punjab, the Khans of Khyber Pakhtunkhwa also have the ownership of a large area of land. But in Khyber Pakhtunkhwa, Khans are not influencing the autonomy of voters. This paper suggests that the landlord's influence is very rare and decreasing with the passage of time. The people get elected for a political office on micro level on the basis of large number of kin members and strong neighbourhood associations.

\subsection{Grass root government}

In Pakistan, the grass root government is the lowest tier of government, in which local candidates are selected on Village Council (here after VC), Union Council (UC), Tehsil and District levels. Before going into the details of micro level politics (VC, UC, Tehsil and District), it is important to describe the history of election system at the micro level in Pakistan. There have been different names of this system i.e. Basic Democracy (here after BD), Local Government System (here after LG), and grass root government. It is evident from the literature that this system is a British legacy. Before partition, during the British rule, this system was implemented with the prime objective to decrease the financial burden on British government and collect taxes (Siddiqui, 1992). After 1947, in Pakistan this system was applied five times, four times during dictatorial governments and only once in a democratic government. In Pakistan, for the first time this government was launched during the era of President Ayub Khan in 1959 named BD, however, later on it failed due to certain reasons (Khan and Khan, 2015, pp. 52-60).

The second term of grass root government was introduced by President Zia ul Haq in 1979, and called it local government system, while the third and fourth time it was brought by General Parveez Musharraf in 2001 and 2005 respectively. Hence, all the three dictators claimed that these elections would be non-party based, but informally all the contesting candidates were backed by political parties. In democratic government, this system was introduced once in 2015. According to the KP local government Act 2013, the structure of district and tehsil is district Nazim and Naib district Nazim, tehsil Nazim and Naib tehsil Nazim elected by the house of district and tehsil members respectively. According to the Act, tehsil Charsadda came under the tehsil Nazim and naib tehsil Nazim. There are total 40 members of tehsil council, in 
which 25 are general members, 9 women, 2 kissan (peasant workers), 2 minorities, and 2 youth members. Tehsil is further divided into UC or municipal committee ${ }^{3}$ (here after MC). The UC and $\mathrm{MC}$ are further divided into VCs. Each VC consists of 12 members including 1 chairman, 6 general counsellors, 1 youth, 1 kissan, 2 women, and 1 minority counsellor. The person among general counsellors becomes chairman who receives more votes. Prima facie, this system was initiated by dictators, so it did not gain importance among the masses. If democratic governments are hesitant in promoting grassroots democracy, it triggers a question about their democratic values and promises of empowering citizens (Alam \& Majdi, 2013). There is tremendous amount of literature on structure and function of grass root democracy. While there is a vacuum of academic studies on the political leaders and voting behaviour's of grass root election. The researchers strived to look for the emergence of political leader and voting behaviour of layman on grass root level. Empirical data depicts that on grass root level family and neighbourhood variables play vital role in micro politics.

\section{Theoretical approach}

Most of the studies encountered political experiences in developing countries and relied on either caste or class or both models. The ethnographies on Pakistani politics also depicts the importance and applicability of caste (Barth, 1959; Egler, 1960; Lyon, 2002) and class (Asad, 1972; Ahmad, 1977; Martin, 2016) models. This study focuses on micro level of politics which is more compatible with Barth (1958) model of fusion and fission. However, Barth model was criticized by different scholars i.e., Asad (1972), Ahmad (1977), and Ahmed (1976). Asad (1972) argues (as cited in Lyon, 2002, p. 60) that Barth did not recognize the significance of class interests when focusing on dyadic contractual relationships in Swat. Asad's critique on Barth in based on the extent to which the individuals truly enter into revokable contractual alliances. While discussing the interests of landlords and non-landlords classes, he states that nevertheless [the landlord] acquires his political authority by virtue of his membership in a politically dominant class, not by persuading freely consenting individuals to become his political followers $(1972,85)$. However, unlike Asad, in the area under study there are certain candidates who belongs to non-landlords' class and won the elections at grass-root level. Similarly, Ahmed (1976) criticizes Barth (1959) argument in different aspects. He states that Barth analysis is synecdochic while generalizing Yousafzai khans who are only one fifth of the whole population of Swat is biased and called it khans' eyes view (1976, pp. 9-12). While taking in consideration all the aspects and critiques the researcher tried to encounter all the inhabitants of Charsadda in order to analyse the extent of kinship and its impact in rise and fall of ANP and JUI-F.

Pakhtuns' kinship system and its role in politics are illustrated by different anthropologists. Discussing segmentary tribes and models of Pakhtuns organization, Ahmed (2017, p. 83) suggests that kinship provides boundless loyalty and group solidarity, "the relationship between kin and politics is cognate and important." While discussing the Pakhtuns of Swat, Barth (1981, p. 58) suggests that in patrilineal society the fusion of interests is situational. The fusion of interest is fathers and sons, fathers and their brothers, father's brothers and their sons, and from the same token with grandfather's and grandfather's brothers, and their descendants. While elaborating the lineage bond Barth $(1981$, p. 58) suggests that the opposition block of close and distant collaterals is overridden in case of external threats and the fusion of two or more ancestors becomes like sibling bonds in one generation of genealogy. Moreover, Barth (1981, p. 58) suggests that the structure of the unilineal descent system explains the political 
organization. For this study the unilineal model suggested by Barth $(1959,1981)$ in the context of electoral politics is used. This model will illustrate the fusion and fission of lineage members in the emergence of leaders in micro politics of the Pakhtuns of Charsadda. While applying this model in the electoral politics, this study suggests that in micro politics the opposition of close and distant collaterals of one genealogy is suspended and the descendants of two or more ancestors make fusion to contest elections against the other distant sub-clans and lineages.

\section{Research methodology}

Ethnographic method was used for this research and the study was conducted in tehsil Charsadda having 25 Union Council's in which 21 and 4 are in rural and urban areas respectively. As the grass root elections are conducted on VC's and UC's level, so the study further zooms into UC's Ghunda Karkana, Sheikho, Rajjar-2 and MC-1 in order to analyse the elections at micro level. The tools for data collection were participant observation, in-depth interviews and focus group discussions. Total 60 in-depth interviews were conducted 20 each from ANP and JUI-F leaders and followers and 20 from floating voters. As Mack and Woodsong (2005) suggest that in-depth interviews are an effective qualitative method for getting people to talk about their personal feelings, opinions, and experiences. The interviews were conducted in both formal and informal discussions. In addition, the data was collected through semi-structured interviews from political leaders, ANP and JUI-F followers and floating voters. Moreover, three FGDs were conducted 1 each with ANP, JUI-F followers and floating voters. In addition, three key informants were selected from the research area keeping in view the characteristic features for key informant as discussed by Trembly and cited in Marshall (1996) i.e. role in community, willingness, knowledge, communicable and impartiality. The data collected for this research covers the duration of eighteen years i.e., 2000 to 2018 in which three grass root elections were conducted. However, the researchers conducted field work of eight months in area under study from January 2018 to August 2018. For the ethical consideration, respondents' names and areas were concealed while using pseudonyms in order to protect the personal secrecy of the respondents.

For the analysis of data, the recorded interviews and discussions were carefully transcripted. Field notes and external documents were repeatedly read. Basic themes were noted separately. The data collection was started with informal discussion with friends, peer groups elders during meetings and different ceremonies that helps in developing of guide for semi structure interviews. During and at the end of each interview important thematic notes were recorded in the diary. In addition, field notes were taken during participant observation which were very useful during the analysis of certain themes. Based on the nature of research topic, different respondents were selected purposively and for data collection different interview guides were developed for detail see annexure 1 . Though one of the researchers personally belong to the area under study, it was an added value to conduct frequent visits to key informants. The local people were well familiar with the research topic. The data and findings were regularly shared with key informants to validate and cross check the information collected from permanent voters and leaders of ANP and JUI-F and floating voters of both Muhammadzai and nonMuhammadzai inhabitants.

\section{Findings and discussion}

In district Charsadda, kinship is important because it identifies khel (segment) which becomes 
the territorial groups. Pakhtuns live in a strong web of paternal and affinal relations. They live with a distinctive code of behaviour and ethics. The basic elements of Pakhtuns' society as Barth (1981, p. 105) mentioned are patrilineal descent, Islam and Pakhtuns' customs. In Charsadda, Pakhtuns are unilineal (patrilineal) descent, but they are also closely linked with complementary filiation. The Pakhtuns are closely connected with both consanguineal and affinal relatives. However, fictive relatives are very rare. They teach their children the basic values and limits of kinship. Similarly, the basic principles of Islam are taught from childhood. All Pakhtuns in the area under study are Muslims and they regularly perform and celebrate Islamic rituals and ceremonies. They always respect religious leaders and their tutelage of both ascribed (Mian, Syed) or achieved through acquiring religious knowledge (ulama, mullah, and pir). They are actively engaged in all rites of passage of the Pakhtuns.

It is evident from the literature that in segmentary lineage societies, kin members and religious saints work as mediators (Barth, 1959; Lindholm, 1977). Pakhtuns' customs are the composite of Pakhtunwali, means Pakhtun code or way of life, Ahmed (2017, p. 89) called it Pakhtuns' ideal form. Both on individual and group level a Pakhtun is bound to follow the derived rules of Pakhtuns' society. Pakhtuns follow reciprocal relationship with all kin members, neighbourhood and friendship associations. As Barth (1959, pp. 31-41) described the importance of kinship and neighbourhood in the socio-political organization of the Pakhtuns of Swat. The relationship is based on the rule that if a person came to participate in my sorrow and joy in return, me and my kin members will obviously participate in his sorrow and joy. Similarly, before going to cast vote, people consider candidate's social organization and his/her relationship with them and with their family members. The following section specifically discusses that in the area under study, kinship and neighbourhood are the major catalysts during electoral politics. These variables are the corner stone in the emergence of political leader at micro level in Pakhtuns' societies.

\subsection{Micro level politics in Charsadda}

The empirical data reveals that at micro level the influence of family in the emergence of leader is significant because agnates are strictly bound to their family norms and values. They do not tolerate a single word against their lineage and family. The role of kinship and neighbourhood ties at the grass root electoral politics can be clearly portrayed by referring to the old English proverb "blood is thicker than water". At micro level, there are certain elders in the family i.e. council of elders which plays an important role in the winning of electoral politics. In

Charsadda, local government elections are based on family, kinship, and neighbourhood. The party affiliation and leadership qualities play a very minimal role at the grass root politics. Hence, for the elections contested at UC and VC levels, different families and neighbourhoods try to nominate their own candidates. These families and neighbourhoods work as campaigners for their candidates. It is evident from the interviews and observations that at the grass root level mostly leaders have their own personal aspiration for electoral politics. It is also evident from the field data that once a person has decided to contest for local government election either as a result of his personal aspiration or with the consent of his family, then he is completely supported by his family members including paternal, maternal, and affinal relatives and neighbourhood.

In the research area, the family members and neighbourhood support their candidate irrespective of his personal attributes required for a political leader as depicted by Weber 
(1919) and Michels (1914) that a political leader is supposed to have the ability to influence people through his wisdom, social activism, and enthusiasm to provide services to create followership in the community.

\subsection{Family and kin group}

Family refers to patrilineal descent only while kinship stands for all paternal, maternal, and affinal relationships in the context of the locale of this study. In most of the anthropological literature, family is considered as the basic unit of kinship, comprising husband, wife, and their children living in a household known as or $^{4}$ by the local people. For the Pakhtuns of Charsadda basic unit of family refers to parents and their children either married or unmarried living in a house. There are also family members who live in separate house as extended family after getting married. Then the family is extended to close relatives from both father and mother sides. They represent these close relatives as " $d a$ me da kor kas $d y$ " means this person belongs to my family. Thus, all these relatives are considered family members. In addition, they also represent these members as kin members.

The kinship system of the Pakhtuns of Charsadda is patrilineal descent. Their common genealogical ancestor is Muhammad, and the people are known as Muhammadzai tribe locally known as Muhammadzai quom (aggregate of people comprising the descendants of Muhammad). The tribe (quom) is further divided in sub-tribes known as khels. The famous khels are paindakhel, yaseenkhel, safarkhel, musakhel, tajukhel, oryazai and other sub-khels. Each khel has its own specified land both in Sholgara (land directly irrigated from river) and Mera (land irrigated through water canals). Their residence pattern is based on geographical distribution of land allotted to different lineages. Kin members of a single khel mostly reside close to each other both in Sholgara and Mera areas. Kin members (locally called Rishtadar) build their houses close to each other while there are also households of non-kin (mostly migrants) in a village. The fellow household (neighbourhood) is either of kin members or nonrelative. The females are allowed to visit each other's households in different ceremonies either they are relatives or nonrelatives but during visit they strictly follow pardha (veil). Adult males are strictly prohibited to visit the distant or non-relatives household.

By considering both patrilineal and maternal relatives as kin members broadens the scope of kinship among Pakhtuns. A Pakhtun has culturally defined links with both father and mother's families (kin members). The males are allowed to visit only the home of close agnates (locally known as tarburan), mother's father (known as mamakhel), and affinal relations wife's father (known as skharganai) households. Hence, a person while considering all agnates, maternal relatives and affinal as kin members makes it easy to clarify the definition of a kin group. Thus, a person's kinship is based on all members of his sub-tribe ( $k h e l)$, and maternal relatives (mamakhel), and parents and siblings of wife (skhargany) are called kins (rishtadar).

\subsection{Family credential for a political leader}

Family plays a dynamic role in the emergence of a leader at the grass-root level of politics. In local government elections, the voters ignore personal qualities of a leader, instead they vote in favor of a leader from their kin. There are certain local leaders whose educational background was very low and did not have any credential associated with social activism but due to the support of their families, they won the local government elections. Such leaders 
lacked the abilities including passion, sense of responsibility, glance, knowledge, and speaking power. There are certain figures in the family and kinship who can completely overcome the weaknesses of a political candidate in such contests e.g. Kurtz (2001, p. 39) depicted in his study that certain agents such as shamans, priests, influential individuals and others are involved in the political process. Similarly, in Charsadda different agents are involved in electoral processes to project their candidate in local government election. At the level of grass root politics, a candidate has limited area of voters, normally his/her UC or VC which comprises of 1000 to 1500 voters. With the help of certain family masharan (elders) they persuade local people to cast votes in favour of their family member. In Charsadda, family members particularly the council of elders as also discussed by Kurtz (2001), plays an important role in the emergence of leader. During field work, numbers of cases were identified that clearly showed the role of other credentials i.e. leadership qualities and political party affiliations are ignored in the politics at the grassroots level.

In one of the cases, for example, Shahab Khan ${ }^{5}$ who emerged as a leader while contesting for general counsellor in 2005 grass root election. Shahab Khan was a small landowner living in a rural area of Charsadda. He belonged to paindakhel sub-tribe descendant of Muhammadzai. The total population of the village was five hundred and fifteen divided in total fifty-nine houses. There were total seventeen houses of his relatives. He was matriculate and a farmer by profession. He was frequently observed in conflict with his agnates and other immigrants of the village. The conflicts were mostly on land issues and in the playground with peer group. His socio-economic status was low as well as he was lacking qualities required for a leader. Before election, a meeting was organized by his family members in hujra. During meeting, four close agnatic relatives including father's brothers, father's parallel cousins were selected who were the most prestigious people of Shahab Khan's family and they also regularly participated in gham khadi of the local people. It was decided in the meeting that during election campaigns these four members would accompany Shahab Khan. His family members knew that Shahab Khan's personal relations with his villagers and other villagers were not good. It was one of the reasons that he was not actively involved during the election campaign. His family members i.e. "council of elders" asked for vote during door to door visits and they also delivered speeches in large gatherings. After a hard struggle of the council of elders, Shahab Khan won the election. Shahab Khan's affiliation was with ANP and his family's council of elder's affiliations was with other parties. Ahmad's political affiliation was with ANP while the rest of the members Zarshad, Haider and Kazim belonged to PPP but irrespective of party affiliation they unanimously supported Shahab Khan. It shows that at the grass-root level of politics, family affiliation is more important than party affiliation. Similarly, in 2015 elections, Olas Khan (PTI) contested for youth counsellor and on the basis of the support from family's council of elders, he won the election.

The following genealogical diagram shows the fusion and fission at micro and macro level elections. It shows that at micro level the family members up to five generation make fusion against the distant family members while at macro level the agnates follow different parties or patrons. In the below genealogy, there are total 25 male voters and all the voters cast their votes to Shahab Khan and Olas Khan in 2005 and 2015 grass root elections respectively, irrespective of their party affiliations. However, at macro level, all the family members follow different secular and religious political leaders in which 16 were floating voters (not firmly associated with parties), 5 were ANP, 1 was JUI-F, and 3 were the permanent followers of PTI. 


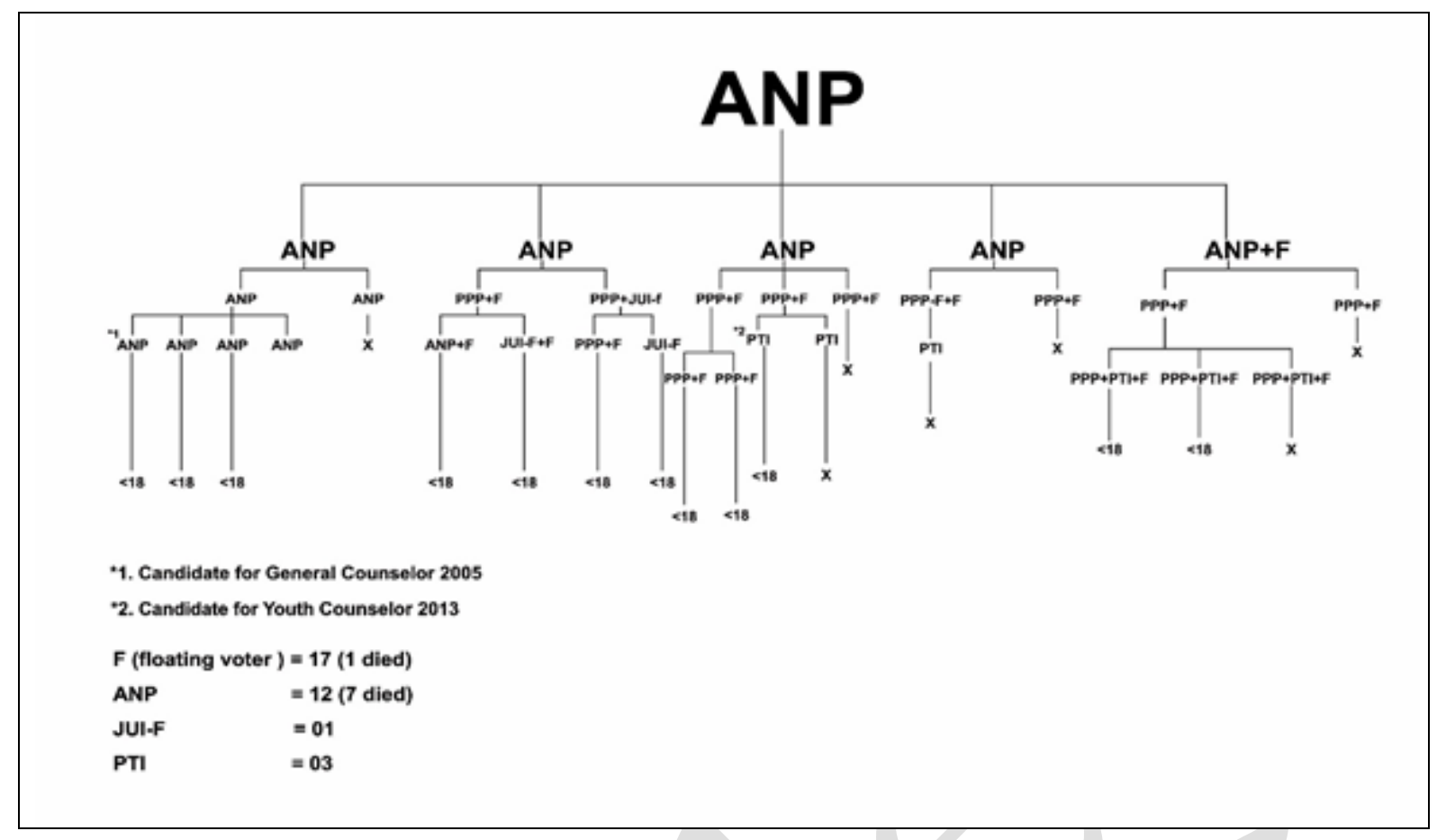

Larger kinship ties in the area is considered as the basic and significant variable for victory in local government elections. Similarly, in MC-1, an urban area of Charsadda, Nawaz Khan won election on the basis of the support from his family. Nawaz Khan is a migrant from Bajaur living in the area for more than fifty years. Nawaz Khan's political affiliation is with JUI-F and most of his family members are with ANP. In 2005 local government election, all his relatives left their party affiliations and cast vote in favour of Nawaz Khan on the basis of family ties. In short, family is the primary and basic factor for an electoral candidate to win election at the micro level.

\subsection{Neighbourhood as a credential for political leader}

After family Kaliwali (neighbourhood) plays an important role in the emergence of political leaders at the grass root level. A Kalay (village) in Charsadda has certain territorial land. Mostly, villages are inhabited by landowner and his family members, immigrants who secured small plots of land, tenants, peasants, ulama ${ }^{6}$ and mullahs $^{7}$, and people of other occupational group. Currently, most of the immigrants and lower class people have secured a small plot of land for houses. Hence, there are some exceptional landlords' villages that consist of their kin members and their peasants and tenants. Most of the villagers' meetings take place in hujra and mosque. They regularly keep in touch with these two places for different social and religious activities. There is a saying that if a Pakhtun is affiliated with hujra and jumat (mosque), he would be more knowledgeable person. It shows that these two places have a vital role in the socialization of Pakhtuns.

From childhood, a person makes different associations with his villagers. On the basis of strong association, they help and support each other in socio-economic and political activities. For invitations of different ceremonies they scrutinize neighbourhoods. They invite their nearby relatives and also some people from the nearby villages. The people are invited on reciprocal basis. On the basis of financial stability and to gain more prestige, landlords and landowners' 
gham khadi (sorrow and joy) ceremonies are more crowded as compared to other villagers. There are also certain people who emigrated to other villages but still visit their old village to maintain socio-economic relationships. The same pattern is highlighted by Barth $(1959$, p. 32) that "this association is patrilineal, people frequently visit their old village if they move and settle in another village". Moreover, in conflict resolution, local landowners and religious leaders play important role as mediators. Hence, a kali (neighbourhood) has its own territory, inhabitants (population), sense of belonging, and governance. In short, kaliwali association is so strong that a village seems to be an alternative of state institution for all the inhabitants.

On the basis of strong relationship inside the village, people always prefer a kaliwal candidate in electoral politics instead of following secular or religious leaders on party basis. In elections, most of the villagers cast votes on the basis of socio-economic ties of neighbourhood. The data reflect that the neighbourhood is the second important factor for an electoral candidate. In an interview, one of the informants shared "I cast vote to Shahab Khan (ANP), Olas Khan (PTI), and Alim Ullah (JI) on the basis of kaliwali. These candidates are living in my village and regularly participate in my gham khadi. Whenever I need someone or something, these people will approach me first even before my relatives if they are residing outside the village".

The informant was a migrant from district Swat and permanent follower of JUI-F. He was also member of party organization at UC level. All the three candidates, he mentioned, were the local inhabitants and belonged to other parties. The importance of these factors was also shared by all the political leaders that they won the elections on the basis of their large kin group and neighbourhood associations. Similarly, a number of immigrants won different elections on the basis of high number of family members and strong neighbourhood ties. In short, family, village, neighbourhood are the basic factors in micro politics for a candidate to win election. A candidate's political power is based on his locality and associations.

\subsection{Comparison of ANP and JUI-F at micro level}

Data from the field depicts that in the area under study local Muhammadzai and immigrants are living in percentage of $40 \%$ and $60 \%$ respectively. The ratio of migrants compared to local inhabitants is higher in Charsadda but their places of origin are different. Their places of origin are districts Mohmand, Bajaur, Dir, Swat, Buner and other districts of KP.

Charsadda is considered as the birthplace of ANP because the founder of the party Abdul Wali Khan son of Khan Abdul Ghafar Khan known as Bacha Khan belongs to the said district. Due to the charismatic qualities of Abdul Ghafar Khan and then his son Wali Khan within a short span of time the party became famous in the whole KP. Similarly, in Charsadda, the party has a large number of followers particularly the local inhabitants. On the other hand, JUI-F a network Islamist party (Ullah, 2014) is also increasing its follower's day by day. In Charsadda, according to a local Alim, there are total 150 madrassas $^{9}$ affiliated with Wifaq-ul-Madaris ${ }^{10}$. Most of the teachers and students of these madrassas are migrants from ex-FATA region. Initially, most of the students came to Charsadda for acquiring religious knowledge and later on permanently settled here. Majority of the JUI-F organization members and followers are ullema and mullahs immigrants. This is one of the reasons that at micro level the party is unable to find influential candidates to contest the election. Maulana Gul Muhammad a Bajure migrant and also has own religious madrassa. He was the JUI-F party president of UC Ghonda Karkana but in 2015 grass root election he was unable to find a candidate to contest the election. 
As discussed, that micro level electoral politics is limited to certain areas (VC, UC) and different candidates both local inhabitants and migrants contesting elections. Most of the local inhabitants contest elections from ANP while the migrant from JUI-F. The migrants of different districts live in scattered form compared to the local inhabitants. In a single village the migrants of different districts live and they have different conflict of interests. While most of the Muhammadzai prefer to live with agnatic cousins to support each other in socio-economic and political life when there is a threat from outsiders. As in UC Ghunda Karkana, Gul Jan Kaly ${ }^{11}$, there were total 58 houses. The division of houses is 17 comprised of local inhabitants of Muhammadzai, 12 of Mohmand, 7 of Bajure, 5 of Dir, 6 each of Swat and Buner, and 5 houses of occupational group. The case of Fayaz Khan, a Mohmand migrant reveals the electoral scenario of Charsadda. While discussing the importance of kinship in politics, Fayaz Khan shared, "I contested the 2015 grass root election for general councillor from UC Rajjar-2 but lost due to the limited number of family members. During the elections my opposite candidates were discussing their number of votes on the basis of family members. Some candidates shared that they had more than hundred votes because of being from large families. While hearing this I realized that I will lose the election because in the whole village and area I have only few family members." The ratio of migrants who won the grass root elections is very low compared to the local inhabitants of Charsadda. The statistical data also show that in micro politics ANP is stronger than JUI-F.

\subsection{Statistical analyses}

It is evident from empirical data that in 2001 and 2005 local government elections ANP had a clear two third majority in Charsadda. While in 2015 election in tehsil Charsadda ANP had majority by winning 8 seats out of 25 . However, in district Charsadda PTI emerged with a majority of two third and elected their district nazim (see appendix 1). From the overall statistics it is evident that ANP voters are greater in number in Charsadda at the grass root level than other secular and also religious parties. Nevertheless, 2015 local government election shows a decrease in the number of followers of both ANP and JUI-F which is an alarming situation for both the parties.

\section{Conclusion}

In this paper, kinship, and its role in the emergence of secular and religious political leaders at micro level was examined. The Pakhtuns of Charsadda are living in a complex network of kinship and label all the relatives in different kin members. In the political context at micro level, kinship and neighbourhood play a significant role in the emergence of a leader. The population of Charsadda was discussed at micro level that shows that Muhammadzai tribe is considered the local inhabitants while the people who emigrated from other districts of KP are considered as non-Muhammadzai. It is evident from the data that kinship variable directly affects the victory and defeat of ANP and JUI-F. Majority of the followers of ANP are the local inhabitants while JUI-F followers are mostly immigrants from other districts who are scattered in different villages. Due to the lack of the majority of local inhabiting followers, the JUI-F was unable to contest and contend ANP at micro level electoral politics. Moreover, ANP lost followers at micro level as well. The statistical data reflects that the number of followers of ANP is decreasing while a new political party, PTI, is emerging in Charsadda. 
Kinship and emergence of political leaders in Pakhtun society: A comparison of ANP \& JUI-F ...

\section{References}

Ahmad, S. (1977). Class and power in a Punjabi Village. Monthly Review Press.

Ahmed, A.S. (1976). Millennium and Charisma among Pathans: A critical essay in social Anthropology. Routledge \& Kegan Paul.

Ahmed, A.S. (2013). The Thistle and the Drone: How America's war on terror became a global war on tribal Islam. Brookings Institution.

Ahmed, A.S (2017). Pakhtun economy and society: Traditional structure and economic development in a Tribal society. Peace Publications.

Alam, M. \& Wajidi, M. A. (2013). Pakistan's devolution of power plan 2001: Dawn for local democracy? Commonwealth Journal of Local Governance, 12(1), 20-34. https://epress.lib.uts.edu.au/journals/index.php/cjlg/article/view/3262

Asad, T. (1972). Market model, class structure and consent: A reconsideration of Swat political organization. Man 7(1), 74-94. https://www.jstor.org/stable/2799857

Barth, F. (1959). Political leadership among Swat Pathans. The Athlone.

Barth, F. (1981). Features of person and society: Collected essays. Routledge \& Kegan Paul.

Eglar, Z. (1960). A Punjabi Village in Pakistan. Columbia University.

Elgie, R. (2001). Political leadership. In Wright, J. (2015). International Encyclopedia of the social and behavioural sciences (2ndeds) (pp. 8578-8590). Elsevier.

Fortes, M. (1953). The structure of unilineal descent groups. American Anthropologist, 55(1), 1741. https://doi.org/10.1525/aa.1953.55.1.02a00030

Hammel, A. (2005). Kinship-based politics and the optimal size of kin groups. The National Academy of Sciences of the USA 102(33), 11951-11965. www.pnas.org/cgi/doi/10.1073/pnas.0504647102.

Khan, I. (1986). Voting behaviour in Rural NWFP: A study of people's participation in Election. Pakistan Academy for Rural Development. https://www.worldcat.org/title/votingbehaviour-in-rural-nwfp-a-study-of-peoples-participation-in-election/oclc/17785199

Khan, S. and Khan, U. (2015). Local government in Pakistan tool for legitimacy: A case study of Gen. Ayub Khan's BD System. The Discourse, 1(1), 49-62.

Kurtz, D. V. (2001). Political Anthropology: Power and Paradigms. Westview Press.

Lewis, H. (1974). Leaders and followers: Some anthropological perspectives. Addison-Wesley.

Lindholm, C. (1977). The segmentary lineage system: Its applicability to Pakistan's political structure. Carolina Academic Press.

Lyon, S. (2002). Power and patronage in Pakistan. Doctoral Dissertation, Department of Anthropology, University of Kent, Canterbury.

Mack, N., \& Woodsong, C. (2005). Qualitative research methods: A data collector's field guide. USAID.http://repository.umpwr.ac.id:8080/bitstream/handle/123456789/3721/Qualitati ve\%20Research\%20Methods_Mack\%20et\%20al_05.pdf?sequence $=1$

Marshall, M. N. (1996). The key informant technique. Oxford University.

Martin, N. (2016). Politics, landlords and Islam in Pakistan. Routledge.

Michels, R. (1914). Political parties: A sociological study of the oligarchical tendencies of modern democracy. Ernest Flammarion.

Mohmand, S. K. (2011). Patrons, brothers and landlords: competing for the vote in rural Pakistan. Doctoral Dissertation, University of Sussex. https://ethos.bl.uk/OrderDetails.do?uin=uk.bl.ethos.554741

Moscona, J., Nunn, N., \& Robinson, J. (2017). Social structure and conflict: Evidence from subSaharan Africa. History, 1(1), 1-39. https://scholar.harvard.edu/files/nunn/files/social_structure_and_conflict_october_2 $\underline{017 . p d f}$ 
Mushtaq, A., Ibrahim, M., \& Kaleem, M. (2013). Dynastic politics in Pakistan. International Journal of Histroy and Research, 3(4), 1-12. http://www.tjprc.org/publishpapers/2-421375764356-1.Dynastic\%20Politics.full.pdf

Omale, S. and Amana, O. (2014). Political leadership crisis and failed states: The function of family imagination. Global Journal of Arts Humanities and Social Sciences, 2(5), 13-24. https://www.eajournals.org/wp-content/uploads/Political-Leadership-Crisis-and-FailedStates-The-Function-of-Family-Imagination.pdf

Peoples, J., \& Bailey, G. (2011). Humanity: An introduction to cultural anthropology (9th Eds.). Cengage Learning.

Rais, R. B. (1985). Elections in Pakistan: Is democracy winning? Asian Affairs: An American Review, 12(3), 43-61. https://doi.org/10.1080/00927678.1985.10553682

Shah. H. (2020). Voting behaviour in Pakistan: An Analysis of partisan and floating voters in General Elections 2013 in Khyber Pakhtunkhwa. Doctoral Dissertation, University of Peshawar, Peshawar, Pakistan.

Shore, C. (2014). Anthropology and political leadership. In Rhodes (Eds.), Oxford handbook of political leadership (pp. 176-192). Oxford University.

Siddiqui, K. (1992). Local government in South Asia. Dhaka University.

Smith, M. (1956). On Segmentary Lineage Systems. Journal of the Royal Anthropological Institute of Great Britain and Ireland, 86(2), 39-80. https://www.jstor.org/stable/2843992

Ullah, H. (2014). Vying for Allah's voter: Understanding Islamic parties, political violence, and extremism in Pakistan. Georgetown University.

Weber, M. (1919). The scientist and the politician. Union General Editions.

Wilder, A. R. (1999). The Pakistani voter: Electoral politics and voting behaviour in the Punjab. Oxford University. 
Kinship and emergence of political leaders in Pakhtun society: A comparison of ANP \& JUI-F ...

\section{Appendices}

Appendix-1: Votes obtained at tehsil and district level

\begin{tabular}{|l|c|c|}
\hline Party Name & Votes obtained at tehsil level & Votes obtained at district level \\
\hline ANP & 44186 & 44356 \\
\hline JUI-F & 36012 & 27658 \\
\hline PTI & 56270 & 60303 \\
\hline QWP & 41113 & 49486 \\
\hline PPPP & 654 & 734 \\
\hline PML-N & 515 & 2001 \\
\hline JI & 32330 & 25730 \\
\hline IND (independent) & 42843 & 44088 \\
\hline
\end{tabular}

Source: Election Commission of Pakistan

Appendix-2: Interview Guides

A. For Floating voter

1. Introduction

2. For how long you are living in this area?

3. Did you cast vote in different elections?

4. To which candidate/ party you cast vote in different elections and on what basis $(2001,2005,2015)$.

5. You casted vote for different candidates/ party in different elections, what was the causes?

6. If personal qualities of the candidate- Why you cast vote to these people and how they attract you?

7. Do you have any family relation with these candidates or party?

8. Did your family member (elder) compel you while casting vote to a party or person?

9. If yes what was the reason? Why and how

10. Did you have any active involvement and interactions with leaders to whom you cast vote?

11. What do you think about the current parties status, its leadership (at VC, UC, tehsil and district levels)

12. What do you think why ANP and JUI-F parties win or lost elections (on what basis)?

B. For Immigrants

1. Introduction

2. What is your place of origin before immigration to Charsadda?

3. For how long you are living in this area?

4. Did you cast vote in different elections?

5. To which candidate/ party you cast vote in different elections and on what basis $(2001,2005,2015)$.

6. What is yours current political party affiliation and why this party?

7. Do you have any family relation with these candidates or party?

8. Did your family member (elder) compel you while casting vote to a person or party?

9. If yes what was the reason? Why and how

10. Did you have any active involvement and interactions with leaders to whom you casted vote?

11. If vote to JUI-F- then why you did not cast vote for ANP as they are representing Pakhtun ethnic group. (if cast vote for ANP then vise-versa)?

12. How is your relation with political leader/ patron (what kind support he provided to you, he is always available when you needed, what kind of support you are expecting from him, is your leader/ patron support you and how? Any example

13. What do you think about the current parties status, its leadership (at VC, UC, tehsil and district levels)

14. What do you think why ANP and JUI-F parties win or lost elections (on what basis)?

15. What do you think, did the immigrants affected ANP/ JUI-F parties politics and how?

C. For Political Leader

1. Introduction

2. How you come to politics (from childhood, family, local people)

3. What was your aim/ objective while coming in politics field? 
4. Yours motive is to serve people ok how you serve people?

5. Which party you have affiliations.

6. There are numbers of parties why you select this one? (attracted from party constitution/ Manshor, election manifesto, etc.)

7. If attracted by party constitution- what are the main points?

8. Who support you while winning the election, what was your strategy to attract voters?

9. How family support you? (financial, social, struggled for you during election, support you during conflict)

10. How is your relation with your voters/ clients (what kind support you are providing to him, you are always available for him when they needed, what are their problems that you resolved, and what kind of support they are expecting?

11. How you attract your clients to support you in the election?

12. There are people who did not have affiliation with any party. What do you think how can be they attracted?

D. For Permanent voter

1. Introduction

2. For how long you are living in this area?

3. Did you cast vote in different elections?

4. To which party you cast vote in different elections and on what basis $(2001,2005,2015)$. On the basis of family affiliation, personal qualities of leader, or the basis of party affiliation.

5. If family affiliation then how?

6. If party affiliation- there are number of other parties why did you chose this party?

7. If personal qualities of the candidate. Why you casted vote to these people and how they attract you?

8. Do you have any family relation with these candidates?

9. Did your family member (elder) compel you while casting vote for a party or person?

10. If yes what was the reason? Why and how?

11. What do you think about the current party status, its leadership? (at local VC, UC, tehsil and district levels)

12. What do you think why your party lost election (on what basis)?

13. Did the party leaders involve directly or indirectly in any conflict/ dispute? (mediator/ biased)

\section{Notes:}

${ }^{1}$ The term Pakhtuns is differently spelled e.g. Pakhtoons, Pukhtuns, Pashtoons, and also the term Pathans is used for Pakhtuns. In this study Pakhtuns is used for plural and Pakhtun for a single person.

${ }^{2}$ For this paper immigrant means internal migrants. The people who emigrated from other districts of KP and permanently settled in district Charsadda.

${ }^{3}$ Municipal committee (MC) represents urban areas of each district of Pakistan.

${ }^{4}$ Kor is relative term Pakhtuns use the word for the compound having boundary walls and rooms and kitchen. Similarly, the local people also use the word for the compound and the people who are residing inside the house.

${ }^{5}$ The name used in this paper are pseudonyms to protect the privacy of the individual concern.

${ }^{6}$ Singular Alim is a person who has completed eight years of Islamic course in a madrassa.

${ }^{7}$ Singular Mullah a person who is a student while acquiring Islamic knowledge.

${ }^{8}$ Hujra is a communal place where male members conducting different activities i.e. meetings, jirgas, and other ceremonies. Barth (1959) called it men's house

${ }^{9}$ Singular madrassa means a religious school

${ }^{10}$ Central board for religious schools/institutions.

${ }^{11}$ Kaly is a Pashto term means village. 